\title{
CAPSAICIN, PHENOLS AND FLAVONOIDS QUANTIFICATION IN LESKOVAC AND HABANERO HOT PEPPERS
}

Dragan T. Veličković1,*, Mirjana N. Virijević1, Ljiljana P. Stanojević², Jelena S. Stanojević2, Ivana S. Mošić ${ }^{3}$, Slađana S. Golubović ${ }^{1}$, Sanja R. Perić1, Grozdan R. Stamenković ${ }^{4}$

\footnotetext{
${ }^{1}$ Academy of Professional Studies South Serbia, Department of Agricultural and Food Studies, Prokuplje, Serbia

2 Faculty of Technology, University of Niš, Leskovac, Serbia

${ }^{3}$ Aromatika doo, Niš, Serbia

4"Zdravlje-Actavis" Company, Leskovac, Serbia
}

Both as food and spice, pepper is unavoidable on the tables in Serbia and many other countries. Because of its popularity, the contents of capsaicin, total phenols and total flavonoids, as well as the antioxidant activity of hot peppers extracts (Leskovac hot pepper, so called "džinka" and chili Habanero pepper) were examined in this paper. The extracts were obtained by Soxhlet extraction with $96 \%$ v/v ethanol. The content of capsaicin in dry extracts of the studied hot peppers was calculated by the HPLC method (13.038 mg/g d.e. for "džinka" and $76.516 \mathrm{mg} / \mathrm{g}$ d.e. for Habanero pepper, respectively). Total phenol and total flavonoids contents were examined by the UVVIS method. Leskovac "džinka" was characterized by both higher contents $(47.17$ mgGAE/g d.e. and $14.64 \mathrm{mgGAE} / \mathrm{g}$ d.e., respectively) in comparison to chili Habanero pepper (29.43 mgGAE/g d.e. and $0.25 \mathrm{mgGAE} / \mathrm{g}$ d.e., respectively). DPPH test was used for the antioxidant activity determination. The $\mathrm{EC}_{50}$ values obtained indicate a better antioxidant activity of Leskovac "džinka" $(1.760 \mathrm{mg} / \mathrm{ml})$ compared to chili Habanero pepper $(6.016 \mathrm{mg} / \mathrm{ml})$.
(ORIGINAL SCIENTIFIC PAPER) UDC 633.842:547.9:66.061

Keywords: Capsicum annuum L., Capsicum chinense Jacq., Capsaicin, Extraction

\section{Introduction}

Pepper fruit (Capsicum spp.) is a very well-known and useful crop worldwide in different cultures and gastronomies [1]. The genus Capsicum comprises more than 200 varieties and five main species: Capsicum annuum (comprising the NuMex, Jalapen o and Bell varieties), Capsicum chinense (Habanero and Scotch Bonnet varieties), Capsicum frutescens (Tabasco variety), Capsicum baccatum (Aji varieties) and Capsicum pubescens (Rocoto and Manzano varieties) [2]. The fruits vary widely in the size, shape, flavour and sensory heat, and total capsaicinoids, colour and volatile compounds were determined [3]. Some of them are a rich source of alkaloid capsaicin (trans-8-methyl-N-vanillyl-6-nonenamide) [4]. The total content of capsaicinoids is usually expressed in pungency. This sum of the concentrations of capsaicinoids is calculated in the Scoville scale [5]. Pure capsaicin has a Scoville heat value (SHV) rating of approximately 16000000 compared to 150000 SHV in habanero peppers [6].

The excessive exposure to capsaicin can cause irritation or respiratory problems, as well as some types of cancers due to high-quantity ingestion [7-9]. Some studies have shown that capsaicin possesses positive effects in the treatment of rheumatoid arthritis and headaches [10]. However, some other studies confirmed its irritative and analgesic properties. Also, it has a slimming effect affecting thermoregulation and the adipose tissue metabolism which is characterized by hypotensive and anticancer effects [11] Anticancer effects of capsaicin are related to the induction of cancer cell apoptosis $[12,13]$. The results of some studies have shown that dietary capsaicin may have a potential use in the prevention of Alzheimer's disease [14] and also in the protection of cardiometabolic organs from dysfunction [15]. Capsaicin may have the influence on hypothermia by the dilatation of blood vessels in the skin and increase the heat exchange. On the other hand, this alkaloid may cause the increase in the metabolic activity [16]. Capsaicin may be used as an ingredient in insect repellents, as well as a biochemical pesticide [17]. Some experiments on cats have shown that capsaicin induced pulmonary chemoreflex consisting of prompt apnea, bradycardia and hypotension [18]. On the other hand, capsaicin applied into the stomach of rats or cats inhibited gastric acid secretion [19].Capsaicin has been used to treat foot pain, laminar ischemia and arthritis [20] in the therapy of animals. In beef cattle studies, capsaicin oleoresin was applied as a feed additive [21].

Capsaicin also possesses antimicrobial effects (against Salmonella typhimurium, Pseudomonas aeruginosa, Saccharomyces cerevisiae, Helicobacter pylori and Streptococcus pyogenes).Because of that, it could be used as a natural inhibitor of pathogenic microorganisms in food [2225]. The antioxidant effect of capsaicin has been reflected on the neutralization of free radicals [26].

\footnotetext{
*Author address: Dragan T. Veličković, Academy of Professional Studies South Serbia, Department of Agricultural and Food Studies, 1 Ćirila i Metodija St, 18400 Prokuplje, Serbia E-mail: dvelickovic7@ptt.rs

The manuscript received: January,13, 2020.

Paper accepted: March, 04, 2020.
} 
The extraction techniques for capsaicin from peppers include maceration, magnetic stirring, enzymatic extraction, microwave-extraction, ultrasound-assisted extraction, Soxhlet extraction, supercritical fluid and pressured liquids extraction [27]. Solid-liquid extraction with solvents such as hexane, chloroform, and ethanol is the most commonly employed method for the capsaicin recovery $[28,29]$. Attuquayefio and Buckle [30] examined capsaicin extraction yields from Capsicum annuum (cayenne pepper) using acetone (the highest yield), chloroform, methanol, acidified methanol, and acetonitrile. Kurian and Starks [31] extracted capsaicin from orange habanero peppers (C. chinense) using methanol and reported yields of $1.25 \mathrm{mg} / \mathrm{g}$ pepper (8840 ppm).

Leskovac chili pepper called "džinka" is a domestic product present in our region since ancient times, unlike Habanero chili pepper which has been found in our market lately. There are no data available in literature for Leskovac "džinka" described in this paper, except for its sensory characteristics that have been examined [32]. Therefore, the aim of the paper was to compare the total phenol and flavonoids content, the antioxidant activity and the capsaicin content of those two hot peppers as frequently consumed products. Further work will be focused on optimizing the extraction process in order to obtain an extract suitable for incorporation into some products (food, pharmaceutical industries, etc.).

\section{Experimental}

\section{Plant material}

Hot pepper "džinka", a type of rosehip (Capsicum annuum L.), was grown on the farm "Stamenković" (Trnjane village, Leskovac municipality). Hot red chili pepper type Habanero (Capsicum chinense Jacq.) was from the farm "Miloševic" (Bogojevce village, Leskovac municipality). The whole pepper fruits were air-dried in a shady site for 15 days during the summer and ground in the electric mill.

\section{Extraction procedure}

Hot pepper extracts were obtained by Soxhlet extraction with $96 \% \mathrm{v} / \mathrm{v}$ ethanol as a solvent. Fifty grams of the plant material and $320 \mathrm{ml}$ of the solvent were used, with 7 presiphons. The final volumes of the extracts were $240 \mathrm{ml}$ (Leskovac "džinka") and $305 \mathrm{ml}$ (Habanero).

The obtained extracts ( $2 \mathrm{ml}$ of the samples) were dried in the dryer at $105^{\circ} \mathrm{C}$ until constant mass and the concentrations of the extracts were calculated on the basis of the dry residue content.

\section{Total phenols content}

Total phenols content was determined according to the Folin-Ciocalteu procedure $[33,34]$ with specified modifications: $0.5 \mathrm{ml}$ methanolic solution of the plant extract $(0.25$ $\mathrm{mg} / \mathrm{ml}$ ), $4.5 \mathrm{ml}$ of water and $0.5 \mathrm{ml}$ of Folin-Ciocalteu reagent were mixed. After 5 minutes, $5 \mathrm{ml}$ of $7 \% \mathrm{Na}_{2} \mathrm{CO}_{3}$ was added. The absorbance was read after 90 minutes at 765 $\mathrm{nm}$ (Cole-Parmer spectrophotometer) against blank con- taining distilled water instead of the extract. Total phenols content was calculated from the calibration curved constructed under the same experimental conditions using gallic acid solutions in the range from $0.00625 \mathrm{mg} / \mathrm{ml}$ to 0.2 $\mathrm{mg} / \mathrm{ml}$ as a standard substance, and expressed as gallic acid equivalents per dry extract (mgGAE/g of the dry extract).

\section{Total flavonoids content}

The total flavonoids content was determined according to the aluminium chloride colorimetric method $[34,35]$. Ethanolic solutions of plant extracts $(2 \mathrm{ml}, 0.25 \mathrm{mg} / \mathrm{ml})$ were mixed with $0.1 \mathrm{ml}$ of $10 \%$ aluminium chloride hexahydrate solution, $0.1 \mathrm{ml}$ of $1 \mathrm{M}$ potassium acetate solution and $2.8 \mathrm{ml}$ of distilled water. After 40 minutes of incubation at the room temperature, the absorbance of the reaction mixture was determined spectrophotometrically at 415 $\mathrm{nm}$ (Cole-Parmer spectrophotometer). Rutin (0.005-0.100 $\mathrm{mg} / \mathrm{ml}$ ) was used as a standard and the total flavonoids content was expressed as rutin equivalents per dry extract (mgRE/g of the dry extract).

\section{Antioxidant activity}

DPPH test was used to determine the capacity of the ethanol extracts to scavenge free 1,1-diphenyl-2-picrylhydrazyl (DPPH) radicals. Dry extracts obtained according to the procedure described above were dissolved in ethanol and the ethanolic extract solutions with different concentrations were prepared. One mililiter of DPPH ethanolic solution $(300 \mu \mathrm{mol} / \mathrm{l})$ and $2.5 \mathrm{ml}$ of the extract ethanolic solution were mixed and after $20 \mathrm{~min}$ the absorbance value at 517 $\mathrm{nm}$ was read (Cole-Parmer spectrophotometer). The scavenging capacity was calculated from the following equation [36]:

DPPH radicals scavenging capacity $=100-\frac{100 \cdot\left(A_{s}-A_{b}\right)}{A_{c}}$

where $A_{s}, A_{b}$ and $A_{c}$ represent absorbance values read at $517 \mathrm{~nm}$ for the ethanolic solution of the extract treated with DPPH radical solution; for the non-treated ethanolic solution of the extract and for the pure, ethanolic solution of DPPH radical, respectively. From the curve of dependence of calculated DPPH scavenging capacities on the concentrations of the extract ethanolic solution, the concentration of the extract needed for neutralization of $50 \%$ of DPPH radical - $\mathrm{EC}_{50}(\mathrm{mg} / \mathrm{ml})$ was determined.

All reagents were of analytical grade. The reagents and standards of gallic acid and rutin were purchased from Sigma-Aldrich (Darmstadt, Germany). All experiments were performed in triplicate.

Capsaicin content in the extracts (HPLC chromatography)

The samples were filtered through $0.45 \mu \mathrm{m}$ filter (Thermo Scientific, Germany) and analyzed with Agilent 1100 Series system (Waldbron, Germany), equipped with a binary pump (Agilent 1100 Series), an autosampler (Agilent 1200 Series) and a DAD detector (Agilent 1200 Series, wavelength range 190-800 $\mathrm{nm}$ ). The sample volume, in- 
jected in the mobile phase under the flow rate of $1.0 \mathrm{ml} /$ min was $10 \mu \mathrm{L}$. The samples were separated into individual components on Zorbax Eclipse Plus C18 column (4.6×250 $\mathrm{mm}, 5 \mu \mathrm{m})$, thermostated at $25^{\circ} \mathrm{C}$. The mobile phase consisted of $0.1 \% \mathrm{v} / \mathrm{v}$ formic acid in water $(\mathrm{A})$ and acetonitrile (B). The samples were eluted using the following gradient: the linear gradient from $0 \% \mathrm{~B}$ to $50 \% \mathrm{~B}$ during the first 30 minutes, followed by the linear gradient to $100 \%$ B from $30^{\text {th }}$ to $40^{\text {th }}$ minute, then an isocratic run with $100 \%$ B for the next three minutes, and finally a linear gradient to $0 \%$ $B$ from $43^{\text {th }}$ to $50^{\text {th }}$ minute. The isocratic run of $0 \% \mathrm{~B}$ for the next 5 minutes was used to re-establish the initial conditions before the injection of another sample. All separated components present in the studied extracts arrived to a DAD detector. The capsaicin content was determined from the signal obtained at $280 \mathrm{~nm}$ corresponding to its absorption maximum wavelength. Ten concentrations of standard capsaicin ranging from $0.006 \mathrm{mg} / \mathrm{ml}$ to $1 \mathrm{mg} / \mathrm{ml}$ were used for the calibration curve construction by plotting the peak area against the concentration of analyte.

\section{Results and discussion}

The content of the dry matter, total phenols and total flavonoids in the extracts are shown in Table 1. The content of the dry matter in the liquid extracts of Leskovac "džinka" $(\mathrm{L})$ and Habanero chili pepper $(\mathrm{H})$ were approximately the same. However, the content of total phenols and total flavonoids was significantly different. The content of total phenols was 1.6 times and of total flavonoids about 60 times higher in Leskovac "džinka" than in Habanero pepper.

Table 1. The content of the dry matter, total phenols and total flavonoids in the extracts

\begin{tabular}{lccc}
\hline \multicolumn{1}{c}{ Sample } & $\begin{array}{c}\text { Dry matter, } \\
\mathrm{mg} / \mathrm{ml}\end{array}$ & $\begin{array}{c}\text { Total phenols, } \\
\mathrm{mgGAE} / \mathrm{g} \text { d.e. }\end{array}$ & $\begin{array}{c}\text { Total flavonoid, } \\
\mathrm{mgGAE} / \mathrm{g} \text { d.e. }\end{array}$ \\
\hline Leskovac "džinka" & $32.00 \pm 1.35$ & $47.17 \pm 0.24$ & $14.64 \pm 0.06$ \\
Habanero chili pepper & $33.45 \pm 0.89$ & $29.43 \pm 0.81$ & $0.25 \pm 0.00$ \\
\hline
\end{tabular}

Pérez-Ambrocio et al. [37] examined the content of bioactive compounds in $C$. chinense. Their results for total phenols $(8.3 \mathrm{mgGAE} / \mathrm{kg})$ and total flavonoids $(9.0 \mathrm{mg} /$ $\mathrm{kg}$ ) did not match our results. They proved that blue and UV-C light may stimulate the synthesis of chlorophylls and total carotenoids (the first days of storage), total flavonoids and phenolic compounds.

The results of the antioxidant activity test are shown in Figure 1 and Table 2. Leskovac "džinka" had a higher antioxidant activity than Habanero for about 3.5 times. According to the total phenols and total flavonoids content shown in Table 1, it could be concluded that these compounds are probably responsible for the antioxidant activity observed. Namely, in the Leskovac "džinka" extract, showing a better activity (lower $\mathrm{EC}_{50}$ value, Table 2 ), a significantly higher content of total phenols and total flavonoids was determined.
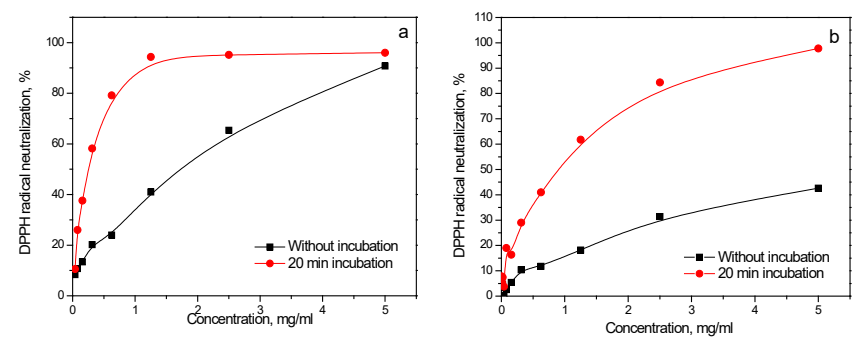

Figure 1. DPPH antioxidant activity (a - Leskovac "džinka"; b - Habanero chili pepper)

Table 2. EC50 values of the extracts from Leskovac "džinka" and Habanero chili pepper

\begin{tabular}{lcc}
\hline \multicolumn{1}{c}{ Sample } & \multicolumn{2}{c}{$\mathrm{EC}_{50}, \mathrm{mg} / \mathrm{ml}$} \\
& Without incubation & $20 \mathrm{~min}$ incubation \\
\hline Leskovac "džinka" & 1.760 & 0.267 \\
Habanero chili pepper & 6.016 & 1.008 \\
\hline EC50 - extract concentration required for neutralization of $50 \%$ of the starting concentration \\
of DPPH radicals
\end{tabular}

Habanero pepper treated with 3 and 0.5 min of blue and UV-C light, respectively, shows higher values of bioactive compounds and the antioxidant capacity during the storage [37]. The antioxidant capacity could be increased depending on the maturity process [38].

The capsaicin content was about 6 times higher in the Habanero chili pepper than in the Leskovac "džinka" (Table 3). HPLC chromatograms of the extracts examined, and the UV/Vis spectrum of capsaicin, as well as the calibration curve of capsaicin are shown in Figures 2-4.

Table 3. Capsaicin content in the extracts

\begin{tabular}{lcc}
\hline \multicolumn{1}{c}{ Sample } & \multicolumn{2}{c}{ Capsaicin content } \\
& $\mathrm{mg} / \mathrm{ml}$ & $\mathrm{mg} / \mathrm{g}$ d.e. \\
\hline Leskovac "džinka" & 0.417 & 13.038 \\
Habanero chili pepper & 2.559 & 76.516 \\
\hline d.e. - dry extract & &
\end{tabular}

d.e. - dry extract

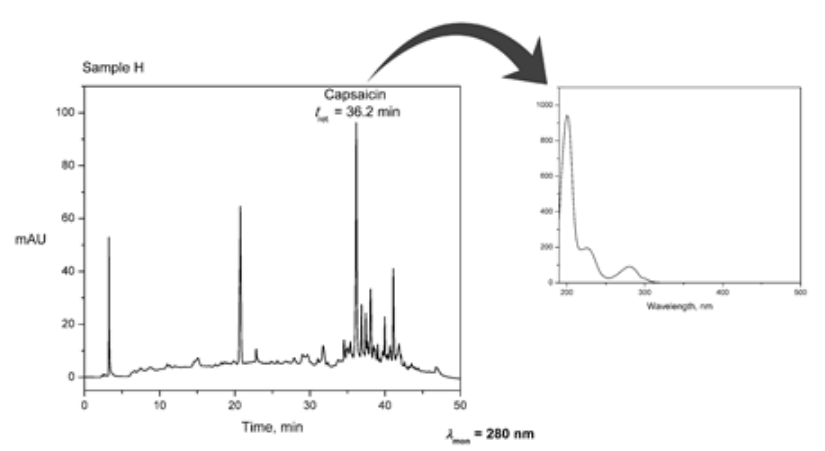

Figure 2. HPLC chromatogram of the extract and UV/Vis spectrum of capsaicin from Leskovac "džinka" 


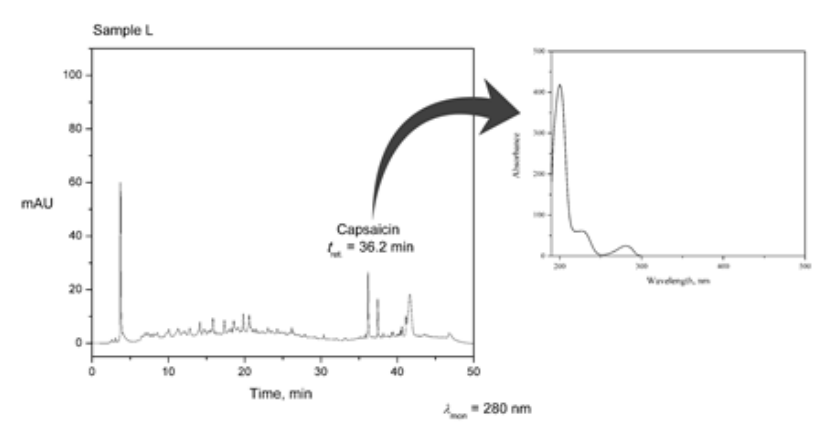

Figure 3. HPLC chromatogram of the extract and UV/Vis spectrum of capsaicin from Habanero chili pepper

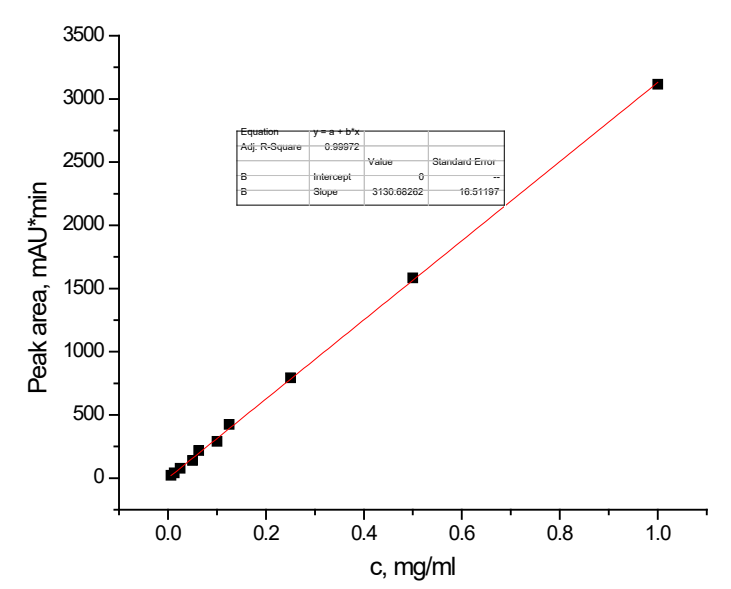

Figure 4. Calibration curve of capsaicin $\left(y=3130.68262 x, R^{2}\right.$ $=0.99972$ )

An insight into the scientific literature reveals that the content of capsaicin (as well as other compounds) depends on the plant species, variety, habitat, temperature, humidity and other conditions. Because of this, there are differences in the content of total phenols and total flavonoids between our hot peppers and the hot peppers grown in other geographical areas. The same refers to the capsaicin content.

During storage, a total capsaicin content increased the reaching values of $39.4 \mathrm{mg}$ of capsaicin $/ \mathrm{kg}$ being responsible for the maturity process [38]. Anatol Schmidt et al. [39] were investigating the relation between capsaicin and dihydrocapsaicin in chilies. The ratio ranged from 1.3 to 4.7 in favor of capsaicin. In Habanero chocolate (placenta and seeds), capsaicin $(12396 \mu \mathrm{g} / \mathrm{g}$ of the dried weight) and dihydrocapsaicin $(3715 \mu \mathrm{g} / \mathrm{g}$ of the dried weight) were found to be the highest. In Habanero orange (whole fruit) the content of the two compounds was slightly lower $(11841 \mu \mathrm{g} / \mathrm{g}$ of the dried weight and $6022 \mu \mathrm{g} / \mathrm{g}$ of the dried weight, respectively).

Total capsaicinoids, color and volatile compounds of 10 Habanero chili peppers (Capsicum chinense Jack.), grouped by their colors: four red, five orange and one brown were determined. The content of capsaicinoids, responsible for the pungency of chili peppers varied be- tween 41.8 and $65.9 \mathrm{mg} / \mathrm{g}$ dry fruit [3].

Lu, Ho and Huang [27] were investigating the extraction process, bioavailability and bio-efficacy of capsaicinoids from different species of peppers. The capsaicin quantity of $0.54 \mathrm{~g} / \mathrm{kg}$ and dihydrocapsaicin of $0.41 \mathrm{~g} / \mathrm{kg}$ of the dried ground sample were found in yellow habanero fruit.

Cisneros-Pineda et al. [40] were examining the content of capsaicin and dihydrocapsaicin in different dry parts of chili peppers (pericarp, placenta, seeds). The capsaicin quantity of $62886 \mu \mathrm{g} / \mathrm{g}$ and dihydrocapsaicin of $1607 \mu \mathrm{g} / \mathrm{g}$ were found in the dry placenta of Habanero orange. The Habanero white placenta contains less capsaicin $29483 \mu \mathrm{g} / \mathrm{g}$ and more dihydrocapsaicin $2349 \mu \mathrm{g} / \mathrm{g}$. Less content was found in pericarp and seeds.

The capsaicinoid extraction from peppers is typically performed using different kinds of solvents (ethanol, acetone and acetonitrile). However, the extraction efficiencies can vary with peppers, their parts (seeds, shells) and pre-extraction processing (freeze and oven drying material) [41]. Capsaicin appears to be a substance with many beneficial effects. It can be cardio-protective, analgesic have an antiinflammatory effect, thermogenic influence, beneficial effects on gastrointestinal system and potential clinical value for pain relief, cancer prevention and weight loss [42]. Therefore, it is proposed to continue studies of the effects of capsaicin with a particular reference to new applications of this alkaloid.

\section{Conclusion}

Unlike Leskovac "džinka”, Habanero chili pepper has been extensively studied. The results shown in this paper were expected with respect to the capsaicin content. Leskovac "džinka" has lower capsaicin content than Habanero. However, other results are in favor of our hot pepper. Leskovac "džinka" has more total phenols and total flavonoids, as well as a more pronounced antioxidant activity. Although it is widely used now, it opens the possibility of being used in the production of various types of food products with a certain amount of spiciness.

\section{Acknowledgement}

This work was supported by the Ministry of Education, Science and Technological Development of the Republic of Serbia under the Program of financing scientific research work, number 451-03-2842/2019-14/172047 and 451-03-68/2020-14/200133.

\section{References}

[1] K. M. Crosby, in Vegetables, II: Fabaceae, Liliaceae, Umbelliferae, and Solanaceae, J. Prohens, F. Nuez Eds., Springer, New York, USA, 2008.

[2] J. S. Pruthi, in Spices and Condiments, E. M. Chichester, G. F. Stewart Eds., New York: Academic Press, 1980, p. 13. 
[3] J. Pino, M. González, L. Ceballos, A. R. Centurió-Yah, J. Trujillo-Aguirre, L. Latournerie-Moreno, E. Sauri-Duch, Characterization of total capsaicinoids, colour and volatile compounds of Habanero chilli pepper (Capsicum chinense Jack.) cultivars grown in Yucatan, Food Chemistry, 104 (2007) 1682 - 1686.

[4] F. Xing, G. Cheng, K. Yi, Study on the antimicrobial activities of the capsaicin microcapsules, Journal of Applied Polymer Science, 102 (2006) 1318 - 1321.

[5] W. L. Scoville, Note on capsicums, Journal of the American Pharmacists Association, 1(5) (1912) 453 - 454.

[6] J. D. Batchelor, B. T. Jones, Determination of the scoville heat value for hot sauces and chilies: an HPLC experiment, Journal of Chemical Education, 77 (2000) 266 - 267.

[7] A. C. Long, D. M. Medeiros, Evaluation of capsaicin's use in analgesic medicine, Journal of Nutraceuticals Functional \& Medical Foods, 3 (2001) 39 - 46.

[8] A. Rosa, M. Deiana, V. Casu, S. Paccagnini, G. Appendino, M. Ballero, M. A. Dessi, Antioxidant activity of capsinoids, Journal of Agricultural and Food Chemistry, 50 (2002) $7396-7401$.

[9] F. Y. Zeyrek, E. Oguz, In-vitro activity of capsaicin against Helicobacter pylori, Annals of Microbiology, 55 (2005) 125 $-127$.

[10] G. A. Cordell, O. E. Araujo, Capsaicin: identification, nomenclature, and pharmacotherapy, Annals of Pharmacotherapy, 27 (1993) 330 - 336.

[11] P. Anand, K. Bley, Topical capsaicin for pain management: therapeutic potential and mechanisms of action of the new high-concentration capsaicin $8 \%$ patch, British Journal of Anaesthesia, 107 (2011) 490 - 502.

[12] V. Di Marzo, L. De Petrocellis, F. Fezza, A. Ligresti, T. Bisogno, Anandamide receptors, Prostaglandins, Leukotrienes \& Essential Fatty Acids, 66 (2002) 377 - 391.

[13] J. R. Friedman, H. E. Perry, K. C. Brown, Y. Gao, J. Lin, C. D. Stevenson, J. D. Hurley, N. A. Nolan, A. T. Akers, Y. C. Chen, K. L. Denning, L. G. Brown, P. Dasgupta, Capsaicin synergizes with camptothecin to induce increased apoptosis in human small cell lung cancers via the calpain pathway, Biochemical Pharmacology, 129 (2017) 54 - 66.

[14] W. Xu, J. Liu, D. Ma, G. Yuan, Y. Lu, Y. Yang, Capsaicin reduces Alzheimer associated tau changes in the hippocampus of type 2 diabetes rats, PLoS One 12, e0172477 (2017).

[15] F. Sun, S. Xiong, Z. Zhu, Dietary capsaicin protects cardiometabolic organs from dysfunction, Nutrients, 8 (2016) 174.

[16] J. Olszewska, Capsaicin - drug or poison, Kosmos, 59 (2010) 133 - 139.

[17] EPA (Environmental Protection Agency), Capsaicin: Reregistration Eligibility Document (RED), National Technical Information Service, Springfield, VA, EPA738-F-92-016, 1992.

[18] M. Szereda-Przestaszewska, B. Wypych, Laryngeal constriction produced by capsaicin in the cat, Journal of Physiology and Pharmacology, 47 (1996) 351 - 360.

[19] O.M. Abdel-Salam, J. Szolcsányi, G. Mózsik, Capsaicin and the stomach. A review of experimental and clinical data, Journal of Physiology (Paris), 91 (1997) 151 - 171.

[20] K. K. Seino, J. H. Foreman, S. A. Greene, T. E. Goetz, G. J. Benson, Effects of topical perineural capsaicin in a reversible model of equine foot lameness, Journal of Veterinary Internal Medicine, 17 (2003) 563 - 566.

[21] I. Fandiño, S. Calsamiglia, A. Ferret, M. Blanch, Anise and capsicum as alternatives to monensin to modify rumen fermentation in beef heifers fed a high concentrate diet, Animal Feed Science and Technology, 145 (2008) 409 417.

[22] L. Dorantes, R. Colmenero, H. Hernandez, L. Mota, M. E. Jaramillo, Inhibition of growth of some foodborne pathogenic bacteria by Capsicum annum extracts, International Journal of Food Microbiology, 57 (2000) 125 $-128$.

[23] S. Kurita, E. Kitagawa, C. H. Kim, Y. Momose, H. Iwahashi, Studies on the antimicrobial mechanisms of capsaicin using yeast DNA microarray, Bioscience, Biotechnology, and Biochemistry, 66 (2002) 532 - 536.

[24] N. L. Jones, S. Shabib, P. M. Sherman, Capsaicin as an inhibitor of the growth of the gastric pathogen Helicobacter pylori, FEMS Microbiology Letters. 146 (1997) 223 - 227.

[25] I. O. Lee, K. H. Lee, J. H. Pyo, J. H. Kim, Y. J Choi., Y. C Lee., Anti-inflammatory effect of capsaicin in Helicobacter pylori-infected gastric epithelial cells, Helicobacter, 12 (2007) $510-517$.

[26] S. J. S. Flora, Structural, chemical and biological aspects of antioxidants for strategies against metal and metalloid exposure, Oxidative Medicine and Cellular Longevity, 2 (2009) 191 - 206.

[27] M. Lu, C. T. Ho, Q. Huang, Extraction, bioavailability, and bioefficacy of capsaicinoids, Journal of food and drug analysis, 25 (2017) 27 - 36.

[28] J. C. Tapia, R. Garcia, E. M. Escamilla, C. Calva, J. A. Rocha, Capsaicin recovery from a cell culture broth, Industrial \& Engineering Chemistry Research, 32 (1993) 2242 - 2246.

[29] O. J. Catchpole, J. B. Grey, N. B. Perry, E. J. Burgess, W. A. Redmond, N. G. Porter, Extraction of chili, black pepper, and ginger with near critical $\mathrm{CO}_{2}$, propane, and dimethyl ether: analysis of the extracts by quantitative nuclear magnetic resonance, Journal of Agricultural and Food Chemistry, 51 (2003) 4853 - 4860.

[30] V. K. Attuquayefio, K. A. Buckle, Rapid sample preparation method for HPLC analysis of capsaicinoids in capsicum fruits and oleoresins, Journal of Agricultural and Food Chemistry, 35 (1987) 777 - 779.

[31] A. L. Kurian, A. N. Starks, HPLC analysis of capsaicinoids extracted from whole orange habanero chili peppers, Journal of Food Science, 67 (2002) 956 - 962.

[32] M. Pestorić, M. Belović, Ž. Kevrešan, J. Mastilović, A Torbica, A. Novaković, Z. Ilić, Contribution of attributes in defining the sensory profile of fresh pepper fruit (Capsicum annuum L.), Journal on Processing and Energy in Agriculture, 19 (2015) 44 - 47.

[33] V. L. Singleton, J. A. Rossi, Colorimerty of total phenolics with phosphomolybdic-phosphotungstic acid reagents, American Journal of Enology and Viticulture, 16 (1965) $144-158$

[34] Lj. P. Stanojević, A. S. Zdravković, M. Z Stanković., M. D. Cakić, V. D. Nikolić, D. P. Ilić, Antioksidativna aktivnost vodeno-etanolnih ekstrakata iz lista koprive (Urtica dioica L.), Savremene tehnologije, 2(1) (2013) 51 - 59.

[35] J. Y. Lin, C. Y. Tang, Determination of total phenolic and flavonoid contents in selected fruits and vegetables, as well as their stimulatory effects on mouse splenocyte proliferation, Food Chemistry, 101 (2007) 140 - 147.

[36] Lj. P. Stanojević, M. Z. Stanković, V. D. Nikolić, Lj. B. Nikolić, Antioxidative and antimicrobial activities of Hieracium pilosella L. extracts, Journal of the Serbian 
Chemical Society, 73(5) (2008) 531 - 540.

[37] A. Pérez-Ambrocio, J. A. Guerrero-Beltrán, X. AparicioFernández, R. Ávila-Sosa, P. Hernández-Carranza, S. Cid-Pérez, C. E. Ochoa-Velasco, Effect of blue and ultraviolet-C light irradiation on bioactive compounds and antioxidant capacity of habanero pepper (Capsicum chinense) during refrigeration storage, Postharvest Biology and Technology, 135 (2018) 19 - 26.

[38] L. A. Castro-Concha, J. Tuyub-Che, A. Moo-Mukul, F. A Vazquez-Flota, M. L. Miranda-Ham, Antioxidant capacity and total phenolic content in fruit tissues from accessions of Capsicum chinense Jacq. (Habanero pepper) at different stages of ripening, The Scientific World Journal, (2014) 1 - 5.

[39] A. Schmidt, G. Fiechter, E. Fritz, H. K. Mayer, Quantitation of capsaicinoids in different chilies from Austria by a novel UHPLC method, Journal of Food Composition and Analysis, 60 (2017) 32 - 37.

[40] O. Cisneros-Pineda, L. W. Torres-Tapia, L. C. GutiérrezPacheco, F. Contreras-Martín, T. González-Estrada, S. R. Peraza-Sánchez, Capsaicinoids quantification in chili peppers cultivated in the state of Yucatan, Mexico, Food Chemistry, 104 (2007) 1755 - 1760.

[41] M. S. Chinn, R. R. Sharma-Shivappa, J. L. Cotter, Solvent extraction and quantification of capsaicinoids from Capsicum chinense, Food and bioproducts processing, 89 (2011) 340 - 345.

[42] Ł. Adaszek, D. Gadomska, Ł. Mazurek, P. Łyp, J. Madany, S. Winiarczyk, Properties of capsaicin and its utility in veterinary and human medicine, Research in Veterinary Science, 123 (2019) 14 - 19.

\section{Izvod \\ ODREĐIVANJE SADRŽAJA KAPSAICINA, FENOLA I FLAVONOIDA U LJUTIM PAPRIKAMA LESKOVAČKA DŽINKA I HABANERO}

Dragan T. Veličković1 ${ }^{1}$ Mirjana N. Virijević ${ }^{\text {, Ljiljana P. Stanojević2 }}$,

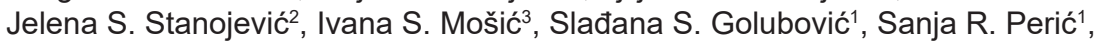
Grozdan R. Stamenković ${ }^{4}$

(ORIGINALNI NAUČNI RAD)

UDK 633.842:547.9:66.061

1Akademija strukovnih studija Južna Srbija, Odsek za poljoprivredno-prehrambene, Prokuplje, Srbija

${ }^{2}$ Tehnološki fakultet, Univerzitet u Nišu, Leskovac, Srbija

3Aromatika doo, Niš, Srbija

4"Zdravlje-Actavis" Company, Leskovac, Srbija

U ljutim paprikama leskovačka džinka i čili habanero određen je sadržaj kapsaicina, sadržaj ukupnih fenola i flavonoida, i antioksidantna aktivnost. Ekstrakti su dobijeni Soxhlet ekstrakcijom sa $96 \%$ V/V etanolom. Sadržaj kapsaicina u suvim ekstraktima ljutih paprika (13,038 mg/g s.e. i $76,516 \mathrm{mg} / \mathrm{g}$ s.e., respektivno) izračunat je HPLC metodom. Sadržaj ukupnih fenola i ukupnih flavonoida određen je UV-VIS metodom. Leskovačku džinku odlikuje veći sadržaj ukupnih fenola i ukupnih flavonoida (47,17 mgGAE/g s.e. i 14,64 mgGAE/g s.e., respektivno) u odnosu na čili habanero (29,43 mgGAE/g s.e. i 0,25 mgGAE/g s.e., respektivno). Za određivanje antioksidantne aktivnosti korišćen je DPPH test. Ekstrakt leskovačke džinke pokazao je bolju antioksidantnu aktivnost (EC50 vrednost: 1,760 mg/ml) od ekstrakta čili habanero (EC50 vrednost: 6,016 mg/ml).
Ključne reči: Capsicum annuum L., Capsicum chinense Jacq., Kapsaicin, Ekstrakcija 